\title{
Fluctuations and Business Cycles Prevention by New Financial Instruments and Banking Structure Reform
}

\author{
Bijan Bidabad \\ B.A., M.Sc., Ph.D., Post Doc. \\ Professor of Economics and Chief Islamic Banking Advisor \\ Bank Melli Iran, Tehran, Iran \\ Email: bijan@bidabad.com
}

\begin{abstract}
Regarding the formation of financial crises in monetary and financial markets of advanced economies and its transmission to other countries through financial markets and foreign trade, a solution is pointed out which is called the reform of financial, monetary and banking structure. In spite of various theories about the source of crises, studies in this field show that usurious banking structures are the main source of crises. The curing method of this economic disease is to prevent somehow the existing time-lag between "deposits interest rates" and "loans interest rates", which creates fluctuations in supply and demand of financial sources. That is to say, banks should not function as a conventional economic firm, but should function as a financial intermediate. Banking structural reform and new financial instruments will be introduced in this regard.Profit and Loss Sharing (PLS) Banking and its subsystems as Joaleh Financial Sharing (JFS) and Mudarebeh Financial Sharing (MFS) with new financial instruments of "Partnership (Mosharekah) Certificate", "Subscripted (Pazireh) Certificates" and "Future Certificate" are introduced at commercial and specialized banking levels. "Interest-Free Bonds" in four different groups of "Central Bank Interest-free Bonds", "Banking Interest-free Bonds", "Treasury Interest-free Bonds" all in varieties on domestic money and Foreign Currency are also introduced which in addition to elimination of usury, can be efficiently used as secure financial instruments at central, commercial and retail banking levels. "Saving QarzulHasanah Certificate" as a kind of Interest-Free Bonds are also introduced. Non-Usury Script-less Security Settlement System (NSSSS) based on information and communication technology has been put forward for creating a secondary market of financial instruments transaction which provides the necessary background for financial structure reform. Squandering prevention and waste prevention and economic ethic teachings are also introduced as supplements in solving crises.
\end{abstract}

Keywords: Business Cycle, Stabilization, Financial Instrument, Bank, Finance, Secondary Market, PLS

\section{Introduction}

In spite of what is mentioned, the occurrence of the crisis was not caused by America's housing sector depression, but the housing sector falls itself was a consequence of the crisis. According to what is proved, the wavy and sinusoid movement nature of economic activities automatically leads to conditions which move the economy from prosperity to depression and crisis and then again to recovery and prosperity. Older theories such as Paul Samuelson theory asserts that these sinusoid movements are caused by the production inventory operations and supply flow. That is to say, when the economy produces more than consumption, commodities accumulate in storehouses, and in order to sell the accumulated inventory, the seller reduces prices. The lowering of commodity prices and the largeness of accumulated inventory will make production sluggish. The producer will be forced to reduce production, and since it decreases the activities of the firm, the income of factors of production (labor, capital, and others) will be reduced. This means the reduction of income at macro-level, which leads to a reduction of demand for goods and services in society as well. Lower income again leads to lower prices and again pushes the economic firm to more depression. This phenomenon continues until the economy turns from depression to crisis. Practically at this stage, the cycle comes to a dead-stop and production stops, because prices can't decrease any more. This creates production incentive (because of supply scarcity and price increase) and income increase of factors of production and demand and prices the economy again moves towards recovery and reaches prosperity, and the economy reaches the beginning situation of the cycle. After a while, depression starts again, and a new cycle starts. 
This phenomenon is the result of the nature of human beings' behavior. That is to say, the nature of people creates this behavior. Since the human being is greedy in consumption and when he is rich, squanders a lot, but limited resources prevent him from continuous squandering and greed. Therefore, economic prosperity stops, because resources do not increase to economic activities of the people proportionally. That is to say, the scarcities of resources increase their prices and reduce profit margin, which is the start of depression and the beginning of the turning towards the lower segment of the business cycle.

\section{Crisis}

Review of economic variables of the United States of America and other industrial nations through the last four decades shows that the behavior manner of financial markets and international commerce spreads crisis from sector to sector and from country to country. Usually, crises start in advanced economies and transmit to other countries. Since the 1960s, the USA faced a current account deficit, while the country increased its budget deficit to stimulate the economy, which led to twin deficits. Since the middle of the 1960s until the beginning of 1980s, the money supply in the USA and most other advanced economies increased more than 10 percent per year which pushed the inflation rate up from the beginning of 1970s and the economy of some other countries such as the United Kingdom faced stagflation ${ }^{1}$. Meanwhile, the fight between Arabs and Israel started, and oil price increased. Some economists believed that the depression of western countries, including the US, was because of oil price increase that increased production markup cost. The beginning of 1980 decade crisis in the US was also coincided with the oil price increase and by applying deregulation policy in financial markets, and the expansion of derivative transactions, and liberation of Saving and Loan Associations activities caused their bankruptcy and depositors drew back their deposits and invested in the stock exchange and derivatives markets. Interest rate increase had a destructive effect on Saving and Loan institutes and caused this crisis to prolong until 1990. There was again a new crisis in US and Europe in 1990 which was also coincided with the oil price increase and second Persian Gulf War which was the trail of hard stock exchange collapse in Black Monday of 1987 which was controlled by Federal Reserve money injection. In 1992, the US economy moved from depression into prosperity, which lasted until 1999. The arrival of new internet innovations caused the flourishing of stocks of internet companies and financial activities on the stocks increased so much that the available assets of this market faced a price bubble. This bubble which was called "Dotcom" bubble burst in 1999. The collapse of the Dotcom market at the end of 1999 pushed the US economy into a new recession which lasted until 2001. But this recession was not accompanied by the oil price increase. The nine eleven attacks faced the depressed economy with a new shock. Federal Reserve encountered this depression by increasing the money supply. Interest rates were decreased, and transactions on real goods such as oil and wheat were changed into financial paper transactions, which were accompanied by a debt crisis. This was because most transactions were for speculation and not for real goods transactions. By interest rate decrease, debt transaction started and intermediaries discounted high-interest rate loans and replaced them with low-interest rate loans. The loans were increased, and the loan was offered even to creditless borrowers with over-priced collaterals. Speculators turned to paper transactions, the results of which were manifested in late 2007. Housing stock market collapsed first and pulled down the value of the stocks based upon the value of collaterals and banks and financial institutes faced bankruptcy. Investors' market confidence vanished, and they turned to real commodity markets. Simultaneously, the atomic quarrel of Iran with western countries increased the oil price growth rate followed by more increase in other bourse commodity prices. The US attack to Iraq and its continuous presence in that country together with special conditions of oil supply and demand, and capital flight from stock markets and their movement toward the gold and oil markets, increased oil prices around $\$ 150$ per barrel and the price of other goods in burses had also such an increase. Depression symptoms were not manifested because oil demand in China, India, and other emerging economies and OECD countries had not decreased. But after a while, oil demand of OECD countries decreased, and by money injection of Federal Reserve of United States of America, investors' confidence was revived, and capital moved from these two markets to other capital markets. Oil price decreased to about $\$ 40$ per barrel and gold price collapsed too. After a while, investors felt that the economy has been stabilized and from another hand, another economic giant (China) entered international scene which had high rate of growth together with India, Brasilia, Turkey, Argentina and other similar countries with high growth rate created a new power in the global scene which decreased the stability and importance of America and Europe in the global economy. The weakening of the role of the United States of America in the global economy was exacerbated by the crisis in Iraq and Afghanistan, while the relations of China and India with middle-east countries were expanded. Meanwhile, the Russia economy revived because it had changed into one of the largest oil and gas exporting countries and gained a major share in Europe

${ }^{1}$ - Of course, more than others, the UK stagflation was due to the economic effects of her colonies freedom. 
energy market. The gas flow cut of Russia to Europe at the peak of cold winter demonstrated the new power balance to western countries. Many advanced countries were more than before worried about the oil market developments and the high level of dependency of western countries, China and India to the Middle East became more obvious and was forecasted that OPEC which is a cartel of 12 oil producing and exporting countries, will soon dominate the oil market.

These developments strengthened the idea that the market is an uptrend and the global demand is improving beyond expectation. This issue will widen the gap between oil producers and consumers and the overcome of the paper market (speculation) over oil market is forecasted and the oil market risk and its global supply can have a destroying effect if there are no solid regulations on oil financial paper transactions. The quick price change of oil prices in derivative markets outside the bourse, where transactions have been more than physical supply and demand transaction facts, can exacerbate the conditions. America and Europe economic developments are so that they can also have quick effects on oil price and will increase it. If the US trade deficit with its trade partners, especially with China reduces, we can expect the downward pressure on the dollar will be reduced, which leads to the lower oil price. But it is not expected that the US twin deficit will decrease in the near future. Therefore, we should expect dollar devaluation and oil price increase, which gained $\$ 100$ per barrel in 2011. Oil consumption in emerging economies is increasing and has increased pressure on the oil price. On the other hand, economic conditions in some European economies are not welcoming, and crisis is transmitting from a country to another in Euro Zone, and we can expect higher oil prices and the continuation of global economic crisis. Although oil price increase can be regarded as a sign of economic growth and entrance to recovery and prosperity, oil price increase expectation which increases oil prices does not reveal this sign, but it is regarded as a higher risk of the economies in future. In other words, the oil price increase based upon the physical increase of oil demand can be regarded as a sign of recovery, and not the oil price increase caused by financial oil paper transactions and speculations.

Economic variables of the last decade bring the great crisis of the 1920 s to mind. The severe oil and grains price increase and successive draughts and unexpected ecological and meteorological events have also exacerbated the problem. Similar conditions were seen in the 1920s. During that decade interest rate was also down, but in spite of low interest rates, the economic condition didn't allow to allocate enough investment in production. The Keynesian quarrel with classic economists can be explained on this subject. Keynes believed that when the economy is in a liquidity trap, or saving and investment are not coordinated; it will be necessary to have a negative interest rate to obtain equilibrium in the money market. It is not possible to use monetary policy in this condition because the interest rate is so low that cannot be lowered any more. Essentially, a liquidity trap occurs when there is a poor relationship between the interest rate and the rate of return in real sector economy. That is to say, regardless of the rate of return of investment, the interest rate goes down. One of the reasons for this condition is risk acceleration of investment, which decreases the net return of investment. The point is: if it was possible to have a negative interest rate which is not practically possible, monetary policy could remove crisis. Therefore, fiscal policies are prescribed for crisis removal, which has been applied in the G20 group by injecting trillions of dollars. Practically, this method moves out the economy from the crisis, but this takes 5 to 10 years to adjust the natural economic powers and move towards prosperity.

\section{Removal of crises by money market reform}

The basic solution of crises which has been neglected by economists is money market reform. Studies ${ }^{2}$ show that usury structure of the banking system is the essential source of crises and in spite of Samuelson view, inventory accumulation is also the result of the crisis and not its cause. Also, in spite of western theories, housing and construction are not the sources of depression, but the crisis is caused by a structural behavior in money and banking sector. Explanation of this theory which has mathematical proofs is that despite conventional economists' view which considers money market as a single market, this market consists of two separate markets; and bank operates

\footnotetext{
2 - Bidabad, Bijan, Stabilizing Business Cycles by PLS Banking and Ethic Economics http://www.bidabad.com/doc/pls-business-cycles-en.pdf http://www.bidabad.com/doc/pls-business-cycles.pdf
} 
as an intermediary between them. In other words, on one side, we have banks' demand market for deposit sources which create interest rate together with deposit supply, which is called deposit interest rate. On the other side, by supplying sources, the bank creates another market in which the supply of financial sources and demand for money sources fixes the interest rate for loans and credit. That is to say; the bank is playing between two markets of financial sources and uses. Now suppose that, because of increased consumption, deposit sources decrease. This will push the deposit interest rate up. This increase cannot push up the loan and credit interest rate. This is because banks loan contracts have terms and bank is obliged to wait for the maturity and then increase the loan interest rate for new loans and then, increase all loan interests. During this period, the bank has to tolerate losses and after a time lag can increase the loan interest rate to compensate for this loss. Although this lag is not very tangible for people, but, from an economic behavior point of view, it creates a special dynamic relation between saving and demand for investment sources. It can be shown mathematically that because of this time lag, the relation is according to a second order difference equation. Second order difference equations have volatility characteristic, which means they create cyclical behavior; therefore, practically transmit the cycles created in the saving-consumption behavior of families sector to production-investment sector. This theory is considered as the most important cause of business cycles, and since the cause has been diagnosed, it can be cured.

The cure of this economic disease is to prevent somehow the time lag between the balance of deposit interest rate and loan interest rate, which create fluctuation in supply and demand of financial sources. That is to say, the bank should not operate as an economic firm, but should operate as a financial intermediate and obtain a commission as income. In traditional economies, banks work as firm and not as intermediates. That is why the banking sector in conventional usurious systems can create market fluctuations. In order to change banks into financial intermediates, we have to describe interest rate performance in the loan sector in a way that her outcomes go to depositors rather than the bank itself. The essential solution of this has been explicitly mentioned in divine books such as Old Testament, New Testament (Bible), and Quran, which is the abolition of usury from monetary activities.

\section{Profit and Loss Sharing (PLS) Banking}

Abolition of usury does not mean stopping the financial activities of the bank, but it means that owners of financial assets do not earn a fixed interest rate on their assets. That is to participate practically in profit and loss of borrower. This Partnership is put forward in different Islamic participation contracts. In these contracts, it is possible that the lender to participates in profit and loss of the borrower. This banking system is classified as "Profit and Loss Sharing" system, which is based upon the doctrine of the abolition of usury in banking activities. Since profit and loss sharing changes bank from economic firm to financial intermediary and practically accomplishes the previous descriptions, it can reach a stable equilibrium by eliminating the time lag between saving market and investment market. On the other hand, risks developed in the loan market will be transferred to saving sector and the borrower and the lender (depositor) together will enjoy profit or loss. ${ }^{3}$

\footnotetext{
3 - When talking about Rastin PLS banking, it should not be considered that we are regarding the banking system of Iran. This is because it can easily be shown that many of Islamic contracts put forward in Usury Free Banking Law of 1983 are intrinsically usurious.

Bidabad, Bijan, Economic-juristic analysis of usury in consumption and investment loans and contemporary jurisprudence shortages in exploring legislator commandments. Proceeding of the $2^{\text {nd }}$ International Islamic Banking Conference. Monash University of Malaysia. 9-10 September 2004. Reprinted in: National Interest, Journal of the Center for Strategic Research, Vol. 2, No. 1, winter 2006, pp. 72-90. Tehran, Iran. http://www.bidabad.com/doc/reba-en.pdf http://www.bidabad.com/doc/reba-fa.pdf

Bidabad, Bijan, Sufi foundation of Islamic economics, money, bank, insurance and finance from a theosophy point of view. http://www.bidabad.com/doc/mabani-erfani-eqtesade-islami.pdf

According to exact definition of usury, Installment Selling contract, Mortgage Hire Purchase and Debt Buying contracts with compound interest in the delay of installment payments are in the domain of usury. Of course by considering all conditions about prohibition of usury, Good (interest-free) Loans, Civil Partnership, Legal Partnership, Direct Investment, Modarebah, Forward Deals, Joaleh (working on behalf), Mozareah (cultivation loan contract), Mosaghat (irrigation loan contract) and Ejareh (rent al contract) are not in the domain of usury. In all above contracts except Good Loan which has no interest and Ejareh in which the rental is pre-defined, interest should not be pre-fixed, otherwise, they will fall in usury realm.

Bidabad Bijan, Non-Usury Bank Corporation (NuBankCo) The Solution to Islamic Banking. Proceeding of the $3^{\text {rd }}$ Islamic economics conference, 2003, Tarbiyat Modarres University, Tehran.

http://www.bidabad.com/doc/NUBankCo-en.pdf

http://www.bidabad.com/doc/sherkat-sahami-bank.pdf
} 
Economic literature has expressed many advantages about risk transference of Islamic banking operations, which are described by Islamic banking researchers ${ }^{4}$, and Islamic banking has been put forward as a financial stabilizer method $^{5}$. But although it has been theoretically explained, Rastin PLS banking has not been practically applied ${ }^{6}$, and this is one of the defects of PLS application ${ }^{7}$. In 2007, Bank Melli Iran started to consider this subject and tried to find a practical solution to PLS banking. ${ }^{8}$ In this regard, an extensive study has been carried out under the supervision of the author, and it is operating as a pilot plan. If this system works successfully, it practically creates conditions in which risk problem of investments will not transmit to banks, and crisis doesn't find ground to spread. This is because practically, Rastin PLS banking diverts risks from credit facility to depositor and bank will not face any losses. On the other hand, the strong and structural relationship between the loan interest rate and deposit interest rate does not allow loss in one market, while the other one is facing profit. That is, when in the loan market, the investor faces loss, the PLS system doesn't allow the transfer of this loss - in the form of profit (interest) - to the depositor. That is, PLS transfers the loss to the depositor, and both markets enjoy more relative stability. Therefore, fluctuations in the loan interest rate in the supply side and deposit interest rate in demand side will become restful.

This is in contrary to conventional banking in which borrower, regardless of obtaining profit or loss, has to pay interest to the lender, and he always gains profit. In the PLS system, if borrower gains profit, the depositor will also gain profit, and if the borrower faces loss, the lender (depositor) will also suffer loss. In PLS system, regardless of the bank to be private or public, the basis for fixing loan rate is the return of real sector economy, and bank operates as intermediate of funds or attorney and receives a commission, and the remaining profit of investment activity is paid to the depositor. Accordingly, agent bank can receive deposits on the basis of PLS contracts by a general or

In other words, if we want to perform Rastin PLS banking, we have to make special changes in current banking system. These changes include from developments in Usury Free Banking Law, elimination of Shariah tricks used by banks and changes in organization of banks. Regarding the usury content of banking system of Iran in recent decades, occurrence of crisis could be forecasted and it is seen, the crisis has been transmitted from industrial countries to Iran and housing depression consequences have been seen in housing sector of Iran which is the effect of the crisis. As it was mentioned before about the basic cause of financial crises, the reason for transmission of the crisis to Iran was the usury content of banking system of Iran, and if it was usury-free, that is, depositor really participated in profit and loss of the borrower, the crisis would not been transmitted to the country. As we see since no country truly conducts Islamic banking, crisis transmits from country to country.

4 - Mahlkecht, Michael (2009). Islamic Capital Markets and Risk Management. London: Risk Books.

5 - Zarqa, Muhammed Anas (1983) :Stability in an Interest-free Islamic Economy: A Note”, Pakistan Journal of Applied Economics, Karachi, (Winter 1983), Vol. 2, pp. 181-88.

6 - Khan, Shahrukh Rafi (1984) “An Economic Analysis of a PLS Model for the Financial Sector”, Pakistan Journal of Applied Economics, Karachi, (Winter 1984) Vol. 3, pp.89-105.

7 - Rosly, Saiful Azhar (2006). Critical Issues on Islamic Banking and Financial Markets: Islamic Economics, Banking and Finance, Investments, Takaful and Financial Planning. Author House.

8 - Bidabad, Bijan; Jina Aghabeigi, Mahasti Naeemi, Azarang Amirostovar, Saeed Salehian, Saeed Nafisi Saraee, Alireza Mehdizadeh Chelehbari, Hojattollah Ghasemi Sayghalsaraee, Bijan Hossainpour, Saeed Sheikhani, Mahmoud Allahyarifard, Mohammad Safaeepour, Nadia Khalili Velaee. Detailed design of Profit and Loss Sharing (PLS) banking. Office of Research and Planning, Bank Melli Iran. 2008, Tehran.

Bidabad, Bijan. A glance at Profit and Loss Sharing (PLS) and the subsystems of Modarebah Financial Sharing (MFS) and Joaleh Financial Sharing (JFS), 2011, Tehran, Iran.

http://www.bidabad.com/doc/negahi-bar-pls-mfs-jfs.pdf

Bidabad, Bijan; M. Allahyarifard. Information and communication technologies in establishment of Profit and Loss Sharing (PLS) Mechanism. Quarterly Journal of New Economy and Commerce, vol. 1, No. 3, winter 2006, pp. 1-37. http://prd.moc.gov.ir/jnec/farsi/3rd/Article2.pdf

http://www.bidabad.com/doc/Pls_it-fa.pdf

Bidabad, Bijan; M. Allahyari Fard. Operational Mechanism of Profit and Loss Sharing (PLS) Banking, Financial innovations of Mosharekeh (Partnership) Certificate and Pazireh (Subscripted) Certificate with international financial efficiency. Presented at the second conference of Banking services and export, Bank of export development, 18 October 2008, Tehran, Iran.

http://www.bidabad.com/doc/PLS-Banking.pdf

http://bidabad.com/doc/PLS-Banking-Export-Deveopment-Bank-2.ppt

http://www.bidabad.com/doc/PLS-banking-Executive-Mechanism.pdf

Bidabad, Bijan; Mohammad Safaeipour. The Electronic Market for Transaction of Mosharekeh (Partnership)/Pazireh (Subscripted) Certificates. Fifth Conference of E-Commerece, 23-24, November 2008, Ministry of Commerce, Tehran, Iran. http://www.bidabad.com/doc/charchoobe-bazare-electronic-pls.pdf http://www.ecommerce.gov.ir/EArchive/EArchiveF/Item.asp?ParentID=43\&ItemID=182 
special participation contract in the form of attorney and invest it according to the decision of depositor, or the bank can divide the outcome between depositors. Then, the real profit is divided between them according to their agreements of the parties and in the framework of regulations. In this regard, the bank carries out its financial intermediary function and after deducting its commission, transfers the results of investment as she is an attorney or agency of depositor.

Because of its intrinsic risk management, development of this banking system will also absorb foreign investors, and since all transactions can be carried out on cyberspace, the place of the transaction can move to anywhere around the world, and other countries will be persuaded to use this kind of banking system. This is because; the essential problem of conventional banking around the world is a financial risk which causes the bankruptcy of the banks. By this kind of banking system, it is possible to solve the problem of falling into crisis, and since the initiation of the disease has been found, Rastin PLS banking can have a curing effect on it.

\section{Partnership (Mosharekah) Certificate and Subscripted (Pazireh) Certificate}

New instruments and innovations such as Partnership Certificate and Subscripted Certificate are used in Rastin PLS banking and bank can issue Partnership/Subscripted Certificates and form the secondary market and activate banking and financial market more efficiently and cause important developments. These new innovations can be transacted on cyberspace internet markets. The existence of these two instruments make it possible to have a financial market similar to the stock exchange for transaction and transfer of deposits, and regarding the developments of investment and production sector practically, the transaction price of these certificates will change. These two new instruments are practically regarded as valuable papers which are used for the transaction of deposits and represent deposits allocated to entrepreneurs' projects by PLS method. Partnership Certificates are nameless papers which are issued with a fixed nominal price and for a certain period of time (investment implementation period) by the Rastin PLS banking branch. Certificates holders are shared in the profit of the implementing project proportional to the nominal value and duration of holding. Bank, according to the request of the holder, invests the deposited money in one of the three products of the bank. Holder of these papers can transact the papers over the counter of the bank, or over the internet, therefore, these certificates are assets which can be transacted internationally. Subscripted Certificate is similar to Partnership Certificate but is used in endless or continuous projects so that after the end of the construction period and the start of operation of the project, the owner of the certificate will become shareholders of the company in proportion to the value and duration of holding the certificate.

\section{Joaleh Financial Sharing (JFS)}

"Joaleh Financial Sharing" is one of the subsystems of Rastin PLS banking system. In this arrangement, regardless of the bank being private or public, the basis for fixing return rate is the rate of return in the real sector and bank as agency and attorney provides intermediary services and receives a commission for the supply of her capital management services. Accordingly, the bank receives borrower (producer) request for financial sources and lender (owner of financial sources or depositor) from two different firms. In this case, the borrower is regarded as a producer or seller. Meanwhile, the bank finances the supplier according to the request of the buyer by the issuance of Future Certificate. In this method, the bank is a financial intermediary which collects financial sources from buyers and gives them to producer or entrepreneur. The entrepreneur is necessarily a legal entity. Joaleh operations under the title of JFS, follow general regulations and instructions of Rastin PLS banking.

\section{Future Certificate}

In order to provide working capital of producing firms on the basis of JFS, a new financial instrument is introduced. This instrument namely "Future Certificate" described below, is quite different from prevailing "Future Contracts" in global stock exchange markets. Future contracts of global stock exchange markets are issued for special goods with defined quality and price, and a percent of the value of the contract is to be reserved at the hands of a third party (usually stock exchange organization), and the seller has to deliver the good to buyer at a certain time in future; otherwise, the reserved value will be transferred to the buyer. Future contracts can be transacted in bourse

${ }^{9}$ Bidabad, Bijan; J. Aqabeigi, A. Amirostovar, A. Hezaveh, A. Shafiei, S. Nafisi Zobdehsaraei, A. Mehdizadeh, A. Hayatdavoodi, B. Hussainpour, S.A. Hussaini, A. Shali, M. Kashefi, M. Allahyarifard, M. Safaeipour, A. Kosari, B. Einollahzadeh, M. Naeimi, N. Khalilivelaei, Shakeri, M. Naseri. Detailed design of Joaleh Finance Sharing (JFS), a sub-system of Profit and Loss Sharing (PLS) banking. Bank Melli Iran, Tehran, 2010. 
and can also be canceled by a new agreement contract between the dealing parties. This action is called "scalability of future contracts". In this contract, the buyer and seller agree on the future price. Arbitrage operations on future contracts will change its transaction vale until its present (cash) value tends towards its future value. Usually, by an offsetting transaction, a future contract can be closed out in clearing house. Commodity futures contracts are different from interest rate future contract on valuable papers such as bonds and to some extents, on foreign exchange futures which involve interest rate in calculating future price as a discount from spot price by considering margin money or, good-faith deposit or earnest money which contains usury. This is because some of these future contracts have predetermined return and the time affects its discount value of spot value, and according to the interest amount, margin money is deduced from its price. In other words, these contracts enter the realm of usury at least equal to the amount of interest related to margin money, and so far margin money is closer to spot price, its usury nature is intensified. Future contracts are used in grain, meat, metals, edible and fiber materials, wood and energy in bourses.

Future contracts are applied to both real or absent goods. Since future contracts are interchangeable; therefore, in future markets, we find many future contracts which do not transact any goods, and just bind obligations between buyers and sellers. This kind of transaction which is included in the broad definition of money as quasi-money increases the number of valuable papers in the economy, which is not controlled by monetary authorities and decreases monetary policy effects. Moreover, no goods or services are produced through these contracts. This is one of the defects of this financial instrument which can push the economy into crisis.

The difference of Future Certificate in Joaleh Financial Sharing (JFS) and future contracts can be explained as follows:

- In Future Certificate, 100 percent of the future price of the transaction is transferred to the seller's account.

- Each issued Future Certificate indicates a transaction of real goods and has no offsetting transaction.

- The seller is a firm with a legal entity.

- Bank operates as a financial intermediate and receives money from the buyer and allocates it to the seller.

- Margin money is just received from the seller (producer) in the form of guaranty or other collaterals.

- At the end of the period of the contract, the contracted commodity is delivered to the buyer according to the contract and under the supervision of the bank, and the contract is closed out.

- Future Certificate can be transacted in the secondary market but with no offsetting. Therefore, the final holder of the certificate will be the owner of real good at maturity and is bound to deliver it.

- The trustee (Amin) unit of the bank will supervise the consumption of allocated financial resources to the producer.

- Future Certificate can be issued for providing working capital of a production firm, but not for her fixed capital.

- Regarding these differences, there will be no paper markets for virtual or absent commodities, and debt leverage crisis will not create economic crises.

\section{Mudarebeh Financial Sharing (MFS)}

"Mudarebeh Financial Sharing (MFS)"10 is one of the subsystems of "PLS banking system". In "Mudarebeh Financial Sharing (MFS)" regardless of the bank being private or public, again the basis for fixing Mudarebeh return rate is the rate of return in the real sector and bank as agent or attorney provides capital management services to the depositor and applies his financial sources into specific business Mudarebeh projects. The yield of Mudarebeh as profit or loss is transferred to the depositor. Accordingly, the agent bank invests the deposits of depositors in a specific project on the basis of the decision of depositor through a sharing contract and divide the results between depositors. Profit or loss will be divided according to compiled instructions. In this regard, in carrying out her

\footnotetext{
${ }^{10}$ Bidabad, Bijan; J. Aqabeigi, A. Amirostovar, A. Hezaveh, A. Shafiei, S. Nafisi Zobdehsaraei, A. Mehdizadeh, A. Hayatdavoodi, B. Hussainpour, S.A. Hussaini, A. Shali, M. Kashefi, M. Allahyarifard, M. Safaeipour, A. Kosari, B. Einollahzadeh, M. Naeimi, N. Khalilivelaei, Shakeri.Detailed design of Modarebah Finance Sharing (MFS), a sub-system of Profit and Loss Sharing (PLS) banking. Bank Melli Iran, Tehran, 2010.
} 
financial intermediary functions, in the framework of agency or attorney, the bank will transfer the investment yield to depositors after deducting her own commission.

Bank compiles contracts between the bank and Mudareb (borrower in Mudarebeh contract) on the basis of Mudarebeh contract according to the depositors' view for financial participation in profit and loss. Bank receives income from offering this service.

Depositor through the secondary market website for Partnership/Subscripted/Future Certificates, or one of the branches dealing with PLS and after consulting with experts about PLS products get the necessary information on depositing and dispensing conditions and selects his proper case. After signing and registering the contract, the system will automatically issue the Partnership Certificate. At the end of the participation period, after receiving information about the method of calculating the profit, accounting/auditing counter will calculate it and pays it to the client (depositor).

MFS plan is applicable based on PLS framework, and essentially prepares special conditions for Mudarebeh participation. In this plan, a bank is also a unit which allocates deposit funds to borrowers for Mudarebeh on behalf of depositors and divides the profit and loss according to special contracts. Contracts between the bank and each side of the contract can be on commission or PLS basis. The entrepreneur (Mudareb) is a real or legal entity who receives the financial share of the Dareb (depositor) according to a certain contract and starts Mudarebeh activity. Amin (trustee) is a unit which supervises the Mudarebeh activity on behalf of the bank.

Mudareb also applies to a PLS bank branch and offers his PLS Mudarebeh proposal. Then after receiving informing commission, bank will put the information about the proposed PLS Mudarebeh project in the information portal of the bank to absorb deposits of depositors. The information of the PLS plan includes economic, technical, and financial justification of the project and the information about the entrepreneur (Mudareb) and...

The entrepreneur assessment unit will study the information about the project entrepreneur (Mudareb) according to related instructions and reports if he is technically and competently capable of conducting this project and send it to project assessment unit. If the assessment were positive, this unit will define the collaterals and guarantees according to the instructions and inform the operator (Mudareb). After signing the contract, according to the contract, the financial sources will be taken from depositor and is given to Mudareb and all related documents including budget, timing, financial needs and method of spending, method of project implementation, its phasing, method of quality control, reporting and finalizing and delivery method of the project will be given to trustee by Mudareb. Periodic reports should be delivered to the accounting/auditing unit of the bank according to the prepared time table. At the end of the project, profit and loss and bank's commission will be calculated according to formulas and related compiled instructions, and the share of depositors will be calculated, and their account will be credited. If there are reports about ceasing or delay in implementation of the project, the corresponding loss will be calculated according to the compiled instructions.

\section{Interest-Free Bonds}

Islamic financial instruments should have two main characteristics: firstly they should be usury-free, and secondly, they should be efficient in the form of policy application, financing, liquidity management of monetary authorities, government and bank and non-bank financial institutes dimensions. One of the most important instruments affecting monetary expansion is bonds. Open market operation through the bond transaction can affect liquidity and other monetary variables such as general price level, interest rate, and thereof supply and demand in the economy through monetary expansion mechanism. Because of the usurious content of conventional bonds, they are not Shariahcomplied, and practical application of this instrument is unlawful. The usurious content of these papers does not let to use them in usury-free banking at central banking and commercial banking level; therefore, this important monetary instrument cannot be applied in usury-free banking. This means that without a novel solution, usury-free central banking has not the necessary instrument to adjust monetary fine-tuning of the economy and neither commercial banks have not reliable instruments for financing and asset and liability management. Solving this essential problem is a turning point in applying usury-free banking policies. Therefore, by putting forward interest- 
free bonds, it is necessary to replace traditional bonds with interest-free bonds for central banking, commercial, and retail banking. Vast studies in this field resulted in the innovation of interest-free bonds. ${ }^{11}$

These bonds or certificates have two maturities. The first maturity is when a certificate expires, and the buyer receives his money back. After that, the buyer of the can obtain an equal loan to her nominal value of the purchased bond simultaneously with receiving his money back. The second maturity is when he pays back his loan and settles his borrowing procedure down. The issuers of these papers can choose the time of the first and second maturities corresponding to her monetary, financial or fiscal policy subject to this condition that multiplication of loan by its duration is equal to multiplication of debt by its duration.

Four interest-free bonds can be introduced which, in addition to compliance with Islamic Shariah, and without any Shariah tricks, are tied to assets and can be used as reliable financial instruments in usury-free banking concerning central, commercial and retail banking. These four interest-free bonds are as follows:

- Central bank interest-free bonds which are issued by the central bank.

- Bank interest-free bonds which are issued by commercial, development and specialized banks and monetary institutes whom are under the supervision of the central bank.

- Treasury interest-free bonds. These bonds are issued by government treasury.

- Commercial interest-free bonds. These bonds are issued with special guarantees by private entities.

\section{Foreign Exchange Interest-free Bonds}

It is possible to issue interest-free foreign exchange bonds similar to interest-free bonds in domestic money. In this connection, the four above cited bonds can be issued in foreign exchange denomination. The issuers and buyers of interest-free exchange bonds are similar to interest-free domestic denomination bonds with the only difference that their nominal value in two periods can be in the same denomination or in two different foreign exchanges. In both cases, especially the second one, which is bought in one currency and sold in another currency, there is no usury involvement doubt. Therefore, according to the above classification, we have again four kinds of interest-free foreign exchange bonds:

- Central bank interest-free foreign exchange bond which is issued by the central bank.

- Bank Interest-free foreign exchange bond issued by commercial, specialized and development banks and financial institutes whom are under the supervision of the central bank. Foreign banks can also enter into this market.

- Treasury Interest-free foreign exchange bond issued by government treasury.

- Commercial interest-free foreign exchange bond which can be issued by private companies and firms which necessitates special guarantees as before.

Issuing interest-free foreign exchange bond's effects are similar to issuing interest-free bonds in domestic money. Moreover, it can stabilize the exchange rate, and the central bank can manage different exchange rates in a short time by changing supply and demand. The effects of this instrument are different, whether its denomination in both periods is the same or not. When both denominations are the same, there will be some kind of hedging for opposite to exchange risk for the buyer. If there are two denominations at the first and second periods, paying it back by another denomination will have hedging effect on the variation of the second denomination foreign exchange. In addition to the central bank, all other banks can enjoy this exchange risk coverage.

\footnotetext{
11 - Bidabad, Bijan; M. Allahyarifard and M. Rabiei. Usury-Free Bonds (in Domestic Money and Foreign Exchange) and Islamic Central Banking Monetary Instruments. Proceedings of the $3^{\text {rd }}$ international conference on development of financing system in Iran with cooperation of center for Technology Studies of Sharif University and IRTI of IDB. 19-20 February, 2011, pp. 517-540. http://www.bidabad.com/doc/Islamic-banking-bond-fa.pdf http://www.bidabad.com/doc/Islamic-banking-bond-en.pdf

Bidabad, Bijan; Abul Hassan, Ben Ali Mohamed Sami, Mahmoud Allahyarifard. Interest-Free Bonds and Central Banking Monetary Instruments. International Journal of business and Management Science. Vol. 3, no. 3, August 2011.
} 
Interest-free bonds are substitutes for conventional bonds and in addition to being usury-free, can efficiently affect money expansion, and are capable of liquidity management and monetary and banking financing. Some of these bonds affect liquidity supply, and some others won't and are neutral. In order to apply efficient monetary policies, the central bank can issue, buy or sell interest-free bonds and carry out monetary tuning adjustment policies. If these papers are issued by commercial and specialized banks or non-bank money institutes which have prudential and legal deposits at the central bank, their bond issuance will have no monetary effect on the economy. If the central bank buys these papers, she will expand the monetary base, and if she sells it, will contract it. If these papers are bought or sold in the framework of government treasury bonds to apply the fiscal policy, they will have different monetary and fiscal effects on the economy and central bank can apply monetary policies by buying or selling government treasury bonds. Using extra reserves of banks and other economic institutes (when some institutes are confronting with liquidity shortages) through issuing these bonds by commercial and specialized banks and interestfree funds does not affect liquidity supply of the economy and is a solution for liquidity risk hedging and debts and obligations covering. If the central bank or government buy or sell these bonds, it will have different expanding or contracting effects on the economy. By obtaining banking guarantees, these papers can be issued by private entities in the framework of interest-free commercial papers for financing private sector.

The secondary market of these papers on internet with "Non-usury Scripless Security Settlement System (NSSSS)" with ability to conduct a base-price-less tender and accepting highest competitive price offered during the tender period makes possible transactions yields at market prices. No base price lower than the nominal value is considered, and price proposals of buyers form the interaction of expected interest rate and inflation rate. In other words, the expected natural interest rate will shape in the first and second periods. In addition, the designed transaction facilities of these papers bring about market efficiency and convergence of their yield toward the yield of other securities and the real economy rate of return.

\section{Saving Qarzul-Hasanah Certificate}

Saving Qarzul-Hasanah Certificate (SQC) as a substitute for bonds finishes the circle of Islamic financial instruments and provides financial market development background inside and outside the country. The outstanding characteristic of these papers is that they are based upon financial assets and have no pre-determined interest coupons (zero coupons) and are based on "loan equal to future debt", or "debt equal to future loan" with "temporal withdraw right" which is given to the other party and by creating reciprocal obligation, the primary market is shaped. The secondary market based upon information technology is designed on NSSSS sub-system in which the buyer will own the paper with his highest competitive price proposal. Another outstanding feature of this financial innovation is that it has no base price below its nominal price and is a substitute for conventional bonds and stabilizes monetary and exchange markets.

Essentially, Saving Qarzul-Hasanah Certificate (SQC) is a document which creates two equal rights between buyer and seller. Essentially, the issuer of this paper undertakes to offer an equal amount of financial sources for the same period to the buyer. The simple description of this concept can be defined in Islamic interchange contract. That is, two persons decide to interchange some special asset for a certain period of time. The first person deposits a certain amount of money with the other one, and the second person deposits the same amount of money with the first person for the same period in the future. In this case, no extra material excess or privilege is given to any of the two parties. In Saving Qarzul-Hasanah Certificate (SQC), the first party is a real or legal entity, and the second party is the bank. On the other hand, since the owner of this paper becomes a rightful person, he can sell his right to a third party. This certificate can be transacted digitally on the internet.

The detailed application plan of "Saving Qarzul-Hasanah Certificate (SQC)" has been prepared for "Bank QarzulHasanah Mehr Iran"12. The special characteristics of "Saving Qarzul-Hasanah Certificate (SQC)" can replace this

12 - See:

Bidabad, Bijan; A. Siahpoush, M. Mirzaei Qazi, S. Aljabouri, H. Nasrollahi, Z. Qolami, A. Sharifi, Amir Shams, Sh. Akbarzadeh. Detailed Design of Qarzul-Hassaneh Saving Certificate (Bond), Bank Qarzul-Hassaneh Mehr Iran. 2011.

Bidabad, Bijan. Legal Analysis of Usury-Free Bonds, 2011. http://www.bidabad.com/doc/legal-analysis-of-non-usury-bonds.pdf 
financial instrument at central banking, commercial and retail banking level in both usury-free and usurious banking systems for usury bonds without including any usury doubt in banking activities. Some of the characteristics of this new innovation are as follows:

- Financing different private and government sectors.

- Micro-financing lower-income people.

- Charity activities.

- Financial policy instrument.

- Monetary policy instrument.

- Replacing usury instruments in the capital market.

- To be used as a banking guarantee and collateral.

- High liquidity degree.

\section{Non-usury Scripless Security Settlement System (NSSSS)}

In spite of the expansion of Islamic and conventional financial methods at the international level, electronic transmission of funds, whether through loan or non-loan, has not been considered enough. In spite of the expansion of Real time Gross Settlement System (RTGS), lack of electronic payment system in information technology systems for investment projects, Automatic Clearing House (ACH), Clearing House of Valuable Electronic Papers and International Bank Account Number (IBAN) and on the other side, the expansion of international inter-bank integrated networks such as Single Euro Payment Area (SEPA), The Society For Worldwide Interbank Financial Telecommunication (SWIFT), Inter Bank Information Network and carried out activities for absorbing international cooperation in financing by exchange sources of different countries have not been successful yet. In this regard, the role of application of electronic payment systems for absorbing foreign investments from retail sources and designing negotiable financial instruments for internet secondary markets should be considered. This plan introduces various investment financing methods in a new model based upon information technology to complete the circle of investment financing with no doubt of usury.

The compliance with Shariah on the one hand, and easy access to international retail exchange funds are two main factors in usury-free innovations of this text. In this direction, designing a new system called "Non-Usury Scripless Security Settlement System (NSSSS)" with usury-free instruments and without any Shariah tricks, and by new innovation of usury-free financial instruments based upon information technology including Partnership Certificate and Subscripted Certificate in Rastin PLS banking, Future Certificate in Joalah Financial Sharing (JFS) and central bank, bank, treasury and commercial interest-free bonds and Saving Qarzul-Hasanah Certificate (SQC) to finance liquidity needs of banks and government and private entities and people the both goals in designing Islamic financial instruments and markets are fulfilled. ${ }^{13}$

This system is designed for Rastin PLS banking instruments and other usury-free financial innovations transactions as cited above. The difference between NSSSS and SSSS systems is in their negotiable papers' transaction instruments. Transactions and settlement process in NSSSS are based upon usury-free transactions and those usuryfree transactions which are not dubious in usury content, while the SSSS system is designed for conventional transactions. A sample of this system has been designed for Rastin PLS banking products of Bank Melli Iran ${ }^{14}$. General characteristics and capabilities of this system are:

- Electronic payment through electronic interbank network cards.

- Possibility of using various denominations (foreign exchanges).

- Application of different languages.

- Possible relation to SWIFT and other electronic payment systems such as PAYPAL.

Bidabad, Bijan Saving Qarzolhasana Cerificate, 2011. http://www.bidabad.com/doc/gavahi-qarzulhasana-pasandaz.pdf

13 - Bidabad, Bijan; M. Allahyarifard, IT-Based Usury-Free Financial Innovations. Proceeding of ECDC $2010,5^{\text {th }}$ International Conference on e-Commerce in Developing Countries: with focus on e-Banking \& e-Insurance. ECDC 2010, 15-16 September 2010. http://www.bidabad.com/doc/non-usury-finance-it-en.pdf

http://www.bidabad.com/doc/non-usury-finance-it-fa.pdf

14 - http://pls.bmi.ir 
- Possibility of using Automatic Clearing House (ACH) for small amounts of money, and ARTGS for higher amounts by using IBAN and other integrated customer identification techniques ${ }^{15}$.

- Creating electronic counters to offer usury-free negotiable papers.

- Possibility of observing buyers and sellers queue and their price proposals.

- Organizing tenders and final selling of Islamic papers according to competitive prices.

- Automatic payment after tender coming out and accepting the proposed highest price in the tender.

- Consolidation and integration with other financial systems and sub-systems in Core Banking.

- Conducting accounting and registration activities, customers' desktop services, following-up of records and processes, auditing, and supervision.

- Generating managerial reports according to the needs of various levels of managers, experts, staff, and customers.

- Comparing various papers (business intelligence) regarding expected profit, maturity, the competence of entrepreneur, and other qualitative characteristics of the valuable products and papers affecting yield and risk.

- Risk management system including liquidity, credit, market, and operational risks.

- Designing blocks, units, and baskets of defined financial certificates.

- Providing analytical and financial engineering tools.

- Coding valuable papers according to international standards.

\section{Squandering and ethic economics as a complementary method in preventing crises}

Ethic economics, as a subject which is always considered in the Islamic economic philosophy, has been rarely considered in new economic theories. We put forward the ethic economics as a new name for old valued subjects in economics, which by considering ethical principles, analyzes the economic phenomena and behaviors. In this view, the aim of economic studies is not just studying material problems without value and ethic observations. But human being ethical values should be considered accompanying with economic analysis in such a way that private and social material benefits should be considered together with spiritual and ethical characters of the human being. This view towards economic problems will put forward two material and spiritual dimensions of human being behaviors in relation to private and social economic areas. This approach assesses private and social behaviors which are different from materialistic view to economics and while accepting scientific economic rules, tries to find material and spiritual welfare in a wider view than pure material.

Another alternative of economic crisis pathology is also returned to human being behavior. We people, who indulge in world loving attributes, and practically, provide conditions for exacerbating the crises. That is to say, we indulge in consumption and are greedy in compiling assets, extravagance and waste, which always widen business cycles. This behavior will exacerbate the crisis with severe depression and sever prosperity. If human being behavior improves her behavior so that ethical and mystical teachings which are prevailing in Islam and other Devin religions to be followed, it practically decreases the severity of the crisis. When we are facing extravagance and waste in society, practically over-consumption behavior will increase crisis oscillations and sooner reach depression and prosperity with higher and harder effects. Therefore, we should try to apply ethical and mystical teachings to human being behavior. That is, people without governmental pushing mechanism, prevent extravagant spending and economic greed.

Squandering means wasting resources and is against the maximization principle of resources' utilization. According to Neoclassic theory of consumer behavior, the consumption is based upon a series of assumptions that some of these assumptions, such as unsaturation of consumption, can be violated in Ethic Economics. According to Neoclassic Economics, people tend to maximize their utility of consumption subject to their priorities for work and leisure times. But practically, consumption utility overcomes leisure time utility. Squandering sources is a kind of wasting resources, but the term of squandering has a wider meaning which includes over-doing in every case, while waste does not have this variety of meaning. Squandering causes waste or throwing away some commodity resources, because of "consumption greed", "looking at Jones", "show-off consumption", "persuading

\footnotetext{
15 - Integrated identification system is being compiled under the PLS experts committee in Department of Organization and Systems of Bank Melli Iran.
} 
consumption", "habitual consumption" or more generally pro-consumption. It was shown ${ }^{16}$ that consumer loses some of her utility by squandering. Therefore she has to work more and rest less to compensate the wasted income sources, without obtaining extra utility. In simple words, squandering wastes peoples' leisure time and the utility of leisure time.

Evidence of squandering in the producer's behavior and production processes are observable. The production line can produce damaged or corrupt raw materials or produced goods or produce goods at a higher price and use factors of production more than the need for various reasons. In other words, the main portion of squandering in production leads to inefficient use of factors of production. Evidence of squandering can be observed in production, total efficiency, a un-optimal combination of factors of production, production damages, and wastes and corruption of products.

Squandering prevention frees a large share of economic resources and labor force and capital which can easily be used by firms during the crisis to breakdown the curve of the business cycle which is moving towards depression and crisis and lead it towards recovery and prosperity again. On the other hand, since we will not face extravagance during prosperity, the economy will not reach the saturation threshold and therefore, before the economy reaches saturation conditions, moves towards depression and experiences light prosperity and light crisis and therefore, the wave domain of business cycle become very narrow which means relative stability of the economy.

Many socio-economic subjects which have been the header of strategic policies of human beings have been prevailing for thousands of years, and Divine wised have described these teachings among their Shariah rules. We can mention one of these subjects as "sustainable development", which is one of the prevailing subjects since the end of the last century. Although this subject as a modern theory was put forward in the $20^{\text {th }}$ century, its classic concepts in ethic economics have been less considered. One other subject is extravagance by the meaning of overconsumption. Generally, this concept coincides with pro-consumption and consumption economics at the national level, but its application at the international level brings special concepts to mind.

Perhaps, in the end, it is convenient to mention that prophets and Divine masters have been the wisest persons on the earth, and it is wisdom, which is the path-finder of goodness and salvation of human being. If human being catches this subject that their teachings are the path-finder of life and make use of their teachings and does not give priority to her own wisdom in one way or other, she will have surely a better material and spiritual life.

References

Ashraf Zadeh, Seyed Hamid Reza, Weekly Reports of Oil Price Forecast, International Institute of Energy Studies, 2011, Tehran, Iran.

Bidabad, Bijan. (2014). New Operational Islamic Banking System, Volume One, Theoretical Foundations, LAP Lambert Academic Publishing, OmniScriptum GmbH \& Co. KG, ISBN: 978-3-659-54463-7.

Bidabad, Bijan. (2014). New Operational Islamic Banking System, Volume Two, Applicational Issues, LAP Lambert Academic Publishing, OmniScriptum GmbH \& Co. KG, ISBN: 978-3-659-55210-6.

Bidabad, Bijan (2018), General Regulatory Framework in Rastin Profit and Loss Sharing Banking (Part IOperational Context). Journal of Business and Finance in Emerging Markets, JBFEM, [S.1.], v. 1, n. 1, p. 11-26, May. ISSN 2580-5568.

\footnotetext{
16 - Bidabad, Bijan; Prodigality in ethic economics. Proceeding of Correcting Consumption Pattern Conference. Institute for Trade Studies and Research, Ministry of commerce, 26 July 2010, pp. 49-76. Tehran, Iran. http://www.bidabad.com/doc/esrafeghtesade-akhlagh.pdf

Bidabad, Bijan; Squandering in Ethic Economics (Consumer and Producer Behaviors Analysis). 2010. http://www.bidabad.com/doc/esraf-eghtesade-akhlagh-en.pdf

Bidabad, Bijan; Overconsumption in Ethic Economics and Sustainable Development. 2010.

http://www.bidabad.com/doc/toseeh-payedar-eghtesade-akhlagh-en.pdf

Bidabad, Bijan; Sustainable development and over-consumption in ethic economics. Proceeding of Correcting Consumption Pattern Conference. Institute for Trade Studies and Research, Ministry of Commerce, pp. 377-400. 26 July 2010, Tehran, Iran. http://www.bidabad.com/toseeh-payedar-eghtesade-akhlagh.pdf
} 
https://doi.org/10.32770/jbfem.vol111-26

http://www.bidabad.com/doc/rastin-regulatory-en-I.pdf

Bidabad, Bijan (2018), General Regulatory Framework in Rastin Profit and Loss Sharing Banking (Part II-Legal Groundwork). Journal of Business and Finance in Emerging Markets, JBFEM, JBFEM, [S.1.], v. 1, n. 2, p. 109-126, Nov. ISSN 2580-5568.

https://doi.org/10.32770/jbfem.vol1109-126

http://www.bidabad.com/doc/rastin-regulatory-en-II.pdf

Bidabad, Bijan (2019), General Regulatory Framework in Rastin Profit and Loss Sharing Banking (Part IIIAuxiliary Provisions). Journal of Business and Finance in Emerging Markets, JBFEM, May, Vol 2, No. 1, pp. 51-65. ISSN 2580-5568.

https://doi.org/10.32770/jbfem.vol251-66

http://www.bidabad.com/doc/rastin-regulatory-en-III.pdf

Bidabad, Bijan, Stabilizing Business Cycles by PLS Banking and Ethic Economics

http://www.bidabad.com/doc/pls-business-cycles-en.pdf

http://www.bidabad.com/doc/pls-business-cycles.pdf

Bidabad, Bijan, Economic-juristic analysis of usury in consumption and investment loans and contemporary jurisprudence shortages in exploring legislator commandments. Proceeding of the 2nd International Islamic Banking Conference. The Monash University of Malaysia. 9-10 September 2004. Reprinted in: National Interest, Journal of the Center for Strategic Research, Vol. 2, No. 1, winter 2006, pp. 72-90. Tehran, Iran. Republished (revised) in: International Journal of Islamic Business \& Management, 3(2), 1$15,2019$.

https://www.cribfb.com/journal/index.php/ijibm/article/view/275

http://www.bidabad.com/doc/reba-en.pdf

http://www.bidabad.com/doc/reba-fa.pdf

Bidabad, Bijan, Sufi foundation of Islamic economics, money, bank, insurance and finance from a theosophy point of view.

http://www.bidabad.com/doc/mabani-erfani-eqtesade-islami.pdf

Bijan Bidabad, Non-Usury Bank Corporation (NUBankCo), The Solution to Islamic banking, Proceeding of the 3rd International Islamic Banking and Finance Conference, Monash University, KL, Malaysia, 16-17

November, 2005. International Journal of Shari'ah and Corporate Governance Research, 2(1), 53-66, 2019.

https://www.cribfb.com/journal/index.php/ijscgr/article/view/276

http://www.bidabad.com/doc/NUBankCo-en.pdf

Bidabad, Bijan; Jina Aghabeigi, Mahasti Naeemi, Azarang Amirostovar, Saeed Salehian, Saeed Nafisi Saraee, Alireza Mehdizadeh Chelehbari, Bijan Hossainpour, Saeed Sheikhani, Mahmoud Allahyarifard, Mohammad Safaeepour, Nadia Khalili Velaee. Detailed design of Profit and Loss Sharing (PLS) banking. Office of Research and Planning, Bank Melli Iran. 2008, Tehran.

http://www.bidabad.com/doc/detailed-pls.pdf

Bidabad, Bijan. A glance at Profit and Loss Sharing (PLS) and the subsystems of Mudarebeh Financial Sharing (MFS) and Joaleh Financial Sharing (JFS), 2011, Tehran, Iran.

http://www.bidabad.com/doc/negahi-bar-pls-mfs-jfs.pdf

Bidabad, Bijan; M. Allahyarifard. Information and communication technologies in establishment of Profit and Loss Sharing (PLS) Mechanism. Quarterly Journal of New Economy and Commerce, vol. 1, No. 3, winter 2006, pp. 1-37.

http://prd.moc.gov.ir/jnec/farsi/3rd/Article2.pdf

http://www.bidabad.com/doc/Pls_it-fa.pdf

Bidabad, Bijan; M. Allahyarifard. Operational Mechanism of Profit and Loss Sharing (PLS) Banking, Financial innovations of Mosharekah (Partnership) Certificate and Pazireh (Subscripted) Certificate with international financial efficiency. Presented at the second conference of Banking services and export, Bank of export development, 18 October 2008, Tehran, Iran.

http://www.bidabad.com/doc/PLS-Banking.pdf

http://bidabad.com/doc/PLS-Banking-Export-Deveopment-Bank-2.ppt

http://www.bidabad.com/doc/PLS-banking-Executive-Mechanism.pdf

Bidabad, Bijan; Mohammad Safaeipour. The Electronic Market for Transaction of Mosharekeh (Partnership)/Pazireh (Subscripted) Certificates. Fifth Conference of E-Commerce, 23-24, November 2008, Ministry of Commerce, Tehran, Iran. 
http://www.bidabad.com/doc/charchoobe-bazare-electronic-pls.pdf

http://www.ecommerce.gov.ir/EArchive/EArchiveF/Item.asp?ParentID=43\&ItemID=182

Bidabad, Bijan; J. Aqabeigi, A. Amirostovar, A. Hezaveh, A. Shafiei, S. Nafisi Zobdehsaraei, A. Mehdizadeh, A. Hayatdavoodi, B. Hussainpour, S.A. Hussaini, A. Shali, M. Kashefi, M. Allahyarifard, M. Safaeipour, A. Kosari, B. Einollahzadeh, M. Naeimi, N. Khalilivelaei, Shakeri, M. Naseri. Detailed design of Joaleh Finance Sharing (JFS), a sub-system of Profit and Loss Sharing (PLS) banking. Bank Melli Iran, Tehran, 2010.

http://www.bidabad.com/doc/detailed-jfs.pdf

Bidabad, Bijan; J. Aqabeigi, A. Amirostovar, A. Hezaveh, A. Shafiei, S. Nafisi Zobdehsaraei, A. Mehdizadeh, A. Hayatdavoodi, B. Hussainpour, S.A. Hussaini, A. Shali, M. Kashefi, M. Allahyarifard, M. Safaeipour, A. Kosari, B. Einollahzadeh, M. Naeimi, N. Khalilivelaei. Detailed design of Mudarebeh Finance Sharing (MFS), a sub-system of Profit and Loss Sharing (PLS) banking. Bank Melli Iran, Tehran, 2010.

http://www.bidabad.com/doc/detailed-mfs.pdf

Bidabad, Bijan; M. Allahyarifard. Usury-Free Bonds (in Domestic Money and Foreign Exchange) and Islamic Central Banking Monetary Instruments. Proceedings of the 3rd international conference on development of financing system in Iran with cooperation of center for Technology Studies of Sharif University and IRTI of IDB. 19-20 February, 2011, pp. 517-540.

http://www.bidabad.com/doc/Islamic-banking-bond-fa.pdf http://www.bidabad.com/doc/Islamic-banking-bond-en.pdf

Bidabad, Bijan; Abul Hassan, Ben Ali Mohamed Sami, Mahmoud Allahyarifard. Interest-Free Bonds and Central Banking Monetary Instruments. International Journal of Business and Management Science. Vol. 3, no. 3, August 2011. , pp. 234-241.

http://dx.doi.org/10.5539/ijef.v3n3p234

http://www.ccsenet.org/journal/index.php/ijef/article/download/11665/8300

Bidabad, Bijan; A. Siahpoush, M. Mirzaei Qazi, S. Aljabouri, H. Nasrollahi, Z. Qolami, A. Sharifi, Amir Shams, Sh. Akbarzadeh. Detailed Design of Qarzul-Hasanah Saving Certificate (Bond), Bank Qarzul-Hassanah Mehr Iran. 2011.

http://www.bidabad.com/doc/gavahi-qarz-tarh-bi-vam.pdf

http://www.bidabad.com/doc/gavahi-qarz-tarh.ppt

Bidabad, Bijan. Legal Analysis of Usury-Free Bonds, 2011.

http://www.bidabad.com/doc/legal-analysis-of-non-usury-bonds.pdf

Bidabad, Bijan Saving Qarzolhasanah Cerificate, 2011.

http://www.bidabad.com/doc/gavahi-qarzulhasana-pasandaz.pdf

Bidabad, Bijan; M. Allahyarifard, IT-Based Usury-Free Financial Innovations. Proceeding of ECDC 2010, 5th

International Conference on e-Commerce in Developing Countries: with focus on e-Banking \& e-

Insurance. ECDC 2010, 15-16 September 2010.

http://www.bidabad.com/doc/non-usury-finance-it-en.pdf

http://www.bidabad.com/doc/non-usury-finance-it-fa.pdf

Bidabad, Bijan; Prodigality in ethic economics. Proceeding of Correcting Consumption Pattern Conference.

Institute for Trade Studies and Research, Ministry of Commerce, 26 July 2010, pp. 49-76. Tehran, Iran.

http://www.bidabad.com/doc/esraf-eghtesade-akhlagh.pdf

Bidabad, Bijan; Squandering in Ethic Economics: Consumer and Producer Behaviors Analysis. 2010. Squandering in Ethic Economics: Consumer and Producer Behaviors Analysis. International Journal of Islamic Business \& Management, 3(2), 30-41. 2019. Retrieved from https://www.cribfb.com/journal/index.php/ijibm/article/view/279

http://www.bidabad.com/doc/esraf-eghtesade-akhlagh-en.pdf

Bidabad, Bijan, Overconsumption in Ethic Economics and Sustainable Development. 2010. Recent Advances in Energy, Environment and Financial Planning, Proceedings of the 5th International Conference on Development, Energy, Environment, Economics (DEEE '14), Florence, Italy, November 22-24, 2014. International Journal of Islamic Business \& Management, 3(2), 42-51, 2019. Retrieved from

https://www.cribfb.com/journal/index.php/ijibm/article/view/280

http://www.bidabad.com/doc/toseeh-payedar-eghtesade-akhlagh-en.pdf

Bidabad, Bijan; Sustainable development and over-consumption in ethic economics. Proceeding of Correcting Consumption Pattern Conference. Institute for Trade Studies and Research, Ministry of Commerce, pp. 377-400. 26 July 2010, Tehran, Iran.

http://www.bidabad.com/toseeh-payedar-eghtesade-akhlagh.pdf 
Bidabad, Bijan, Ethic Economics, Fair Economy, New Economy, Sustainability and other Related Disciplines. In Dominique de Courcelles, Editor, “Actes pour une économie juste”. June 2015. International Journal of Islamic Business \& Management, 3(2), 24-29, 2019. Retrieved from

https://www.cribfb.com/journal/index.php/ijibm/article/view/278

http://www.bidabad.com/doc/fair-economy-en.pdf

Bidabad, Bijan, Equilibrium in Ethic Economics. International Journal of Islamic Business \& Management, 3(2), 16-23, 2019. Retrieved from

https://www.cribfb.com/journal/index.php/ijibm/article/view/277

http://www.bidabad.com/doc/taadol-eghtesade-akhlagh-en.pdf

http://pls.bmi.ir

Khan, Shahrukh Rafi (1984) “An Economic Analysis of a PLS Model for the Financial Sector”, Pakistan Journal of Applied Economics, Karachi, (Winter 1984) Vol. 3, pp.89-105

Mahlkecht, Michael (2009). Islamic Capital Markets and Risk Management. London: Risk Books.

Rosly, Saiful Azhar (2006). Critical Issues on Islamic Banking and Financial Markets: Islamic Economics, Banking and Finance, Investments, Takaful and Financial Planning. Author House.

Zarqa, Muhammed Anas (1983): Stability in an Interest-free Islamic Economy: A Note”, Pakistan Journal of Applied Economics, Karachi, (Winter 1983), Vol. 2, pp. 181-88.

\section{Copyrights}

Copyright for this article is retained by the author(s), with first publication rights granted to the journal.

This is an open-access article distributed under the terms and conditions of the Creative Commons Attribution license (http://creativecommons.org/licenses/by/4.0/) 